\title{
Human cataract prevalence study in the district of Alappuzha
}

\author{
Aleyamma kuruvilla* M.Phil, Dr. Issac Thomas ${ }^{1}$ P.HD \\ * Assistant professor, Dept. of Zoology, St. Thomas College, Ranni, Kerala. \\ 1.Research Guide, PG. Dept. Of Zoology,St. Berchman's College, Changanassery.
}

\begin{abstract}
Aim:-Hospital based study from April 2005 to March 2011 conducted among the population to determine the prevalence of cataract in Alappuzha district of Kerala state of India.

Methodology:-The data's collected from registers of ophthalmology department of district hospital and two private hospitals in Alappuzha district to access the gender prevalence and prevalence of different age groups. The total number of cataract operation carried in Alappuzha district was collected from Directorate of Health, Thiruvananthapuram to evaluate the prevalence among the total population Significance were analysed using student's t-test (mat lab).

Result:- Among the total population cataract prevalence in Alappuzha district was significantly $(p=0.0010)$ increased from $0.26 \%$ to $0.37 \%$ within six years. Gender prevalence is significantly higher in females $(60.6 \%, p=0.0000344)$ than in males, suggest that more cataract patients are females. A significantly highest prevalence recorded in the age group of 61-70 years $(40.2 \%, p=0.000044)$ compared with all other age groups.

Conclusion:-The present study of cataract prevalence in Alappuzha district may to some extend throw light on the gravity of cataract incidence in Kerala state. Cataract blindness in Kerala can be effectively controlled only if effective strategies are developed to reduce the incidence of blinding cataract.
\end{abstract}

Key words: Cataract, Prevalence

\section{Introduction}

Cataract is the leading cause of visual impairment world wide, with approximately 37 million people affected according for $48 \%$ of global blindness 1 . It is estimated that there are about 12 million blind people due to cataract in India alone. In India cataract operations has increased from 1.2 million in 1989 to 2.7 million operations in 1996. However impressive this increase may be, the figure does not indicate the extend to which the problem of cataract blindness has been reduced 2. Treatable blindness, particularly that associated with cataract and refractive error, remains a significant problem among older adults in south Indian population especially in females, the illiterate and those living in rural areas 3. Refractive errors (33.8\%) and Cataract (21.4\%) account for more than half of the OPD attendance at a military hospital in Ladakh, North India 4. A global initiative for the elimination of avoidable blindness under the title "VISION 2020: The Right to Sight" was launched in 1999 by the World Health Organization5 in collaboration with a number of international nongovernmental organization. The objectives of this initiative is to facilitate reduction of blindness worldwide by bringing together the resources needed to do so. The major disease related issue that need to be addressed in the eye care policy of India, if the global VISION 2020 to eliminate avoidable blindness is to be achieved are (i) improvement in the quality of cataract surgery and increase in the number of surgeries on persons blind in both eyes, (ii) effective screening to detect refractive error blindness and provision of spectacles and (iii) initiation of long-term strategies to prevent corneal and glaucoma blindness..

\section{Patients \& methodology}

The present study of cataract prevalence in Alappuzha district may to some extend throw light on the gravity of cataract incidence in Kerala state. Alappuzha lies at the western part of Kerala. It is the smallest district of the state of Kerala. The total area of Alappuzha is 1,414 sq. km. It comprises a total population of $21,21,943$ with a density of population being 1,501 persons per sq. $\mathrm{km}$, according to the census of 2011. Among the total population 10,10,252 are males and 11,11,691 are females. In the recent days, it has developed as a major backwater tourist centre and is renowned for its pristine beaches, exciting boat races, romantic houseboat holidays and coir industry. Kuttanad, also known as the rice bowl of Kerala is located at the centre of the backwaters and encompasses a large cultivated region of crops.

This study was conducted among the patients visiting the district hospital and two private hospitals in Alappuzha district which offered special eye hospitals for patients. The period of study was from April 2005March 2011 ie about the six financial years. Methodology comprised of interviewing the patients, checking of medical records etc. The patients of all age included in this survey. The number of cataract operation performed 
was used as a gauging system in this study to find out the impact of cataract on health care system. Prevalence value and distribution of age and gender were analyzed using available information. As per the statistics department (Registrar general),the census of Kerala for the year 2001, 2011 and percentage decadal growth of the population were used in the estimation of prevalence and incidence in this population based study. Significance were analysed using student's t-test (mat lab).

\section{Result}

Prevalence among the total population-A highly significant $(\mathrm{p}=0.0010)$ increase in cataract prevalence can be noticed from 2005-06 (0.26\%) to 2010-11(0.37\%, $\mathrm{n}=7931)$ in Alappuzha district. As shown in the table -1, seven thousand nine hundred and thirty one entries on cataract surgeries (2005-06) in Alappuzha district with a prevalence of 2.6\%. In Alappuzha there was a significant increase noticed from 2005-06 to 200910 i.e from $0.26 \%$ to $0.32 \%$ ( $\mathrm{p}=0.0011$ ). A decrease noticed in between the study. Prevalence decreased in the year $2008-09$ ie. $0.25 \%(\mathrm{n}=5253)$. Among the 10,000 population cataract prevalence highly increased from 26.42 to 37.38 (2005-2011) in this coastal district.

Gender prevalence- A total of 9,575 individuals in all age groups were enumerated in 6 year period starting from 2005 (table-2). Among the total 39.4\% ( $\mathrm{n}=3772)$ were males and 60.6\% $(\mathrm{n}=5803)$ were females. The female gender shows a highly significant $(\mathrm{p}=0.000034)$ increase in Alappuzha district.

Prevalence in different age groups -Case history 9,575 patients were collected from the operation registers of different hospitals in Alappuzha district. The highest age recorded was 97 years. A significantly high prevalence was found in the age group $61-70$ ie. $40.2 \%(n=3849, p=0.000044)$ in this coastal district. Congenital cataract (0-15) with prevalence of $0.6 \%$ (graph-3). Prevalence between the age group of 51-80 was $86.7 \%$. As shown in table-3 less prevalence is above 91 years $(0.3 \%)$ of age.

\section{Discussion and conclusion}

The present study shows that human cataract prevalence is increasing in Alappuzha district. Blindness due to cataract in India is estimated to have a prevalence of $0.8-1 \% \quad 6,7$ causing $62 \%$ of bilateral blindness in persons aged 50 years or more 6,8 . Translating this into numbers, there were an estimated 9 million blind people 6,9 and 32 million moderately visually impaired due to cataract in $20006 ., 10$. Compared with other countries, especially those that are developed, cataract occurs at a much earlier age in India 6. India is a country in demographic transition. Its population will get older, and consequently, the prevalence of cataract will increase further 11. If there was no change in the current trend of blindness, the number of blind persons would increase to 24.1 million in 2010 and to 31.6 million in 202010 .

According to this study females have significantly higher prevalence than males. Prevalence of the low vision and the blindness were higher in females than in males $(\mathrm{p}<0.005) 12$. It has been shown in Australian Blue Mountain study 13,14 that females gender is generally associated with increased age adjusted risk of cataract and the findings of this study is also similar to the Australian Study. Accordingly, the blindness problem remains challengingly high 15 . The women who started menstruating late are at an even higher risk 16. In the higher age groups, women tend to suffer from cataract more than do males. This appears to be true particularly in western countries 17; in view of the well known difficulties of distinguishing between senile and diabetic cataract, it is worth recalling that at least in the U.S.A., women above about 50 years of age have significantly high blood sugar level than men. Other suggestive epidemiological correlations are found to exist. Women are almost 40 percent more likely to develop cataract than men. Women who get more lutein, zeaxanthin and vitamin $\mathrm{E}$ are less likely to develop cataract than women who skip on those nutrients 18 .

In coastal district Alappuzha highest prevalence recorded in the age group of 61-70 years( $\mathrm{p}=000044)$. Increase in blindness prevalence among people aged 50 years and above was observed compared to earlier studies. Those aged 70 and above had a five times higher risk of being blind compared to those aged 50-59 years 8. Prevalence of blindness among people aged 50 years and above has reduced from $9.8 \%$ in the same 15 states in the 1986-89 survey, to $8.5 \%$ in the national survey. A population-based study of lens opactities, the proportion of population who have undergone cataract surgery has a marked increase in the decades after 40 yrs.19 Incidence of cataract surgery in united state is high among those over 70 years, with an annual increase of about 14\% 20 . Programs to further reduce the burden of visual impairment need to be targeted toward the correction of refractive error and surgery for cataracts in Brazilian city 21. The trend of increasing incidence of cataract with increase age is a major public health concern with an aging population in Australia and the world 22.

Overall the survey indicates a high prevalence of human cataract in Alappuzha district. The high rate of cataract blindness in Alappuzha is a clear indication that the cataract blindness in Kerala is too massive to be solved by the surgical programme alone. Cataract blindness in Alappuzha as well as in Kerala can be effectively controlled only if effective strategies are developed to reduce the incidence of blinding cataract. 


\section{References}

[1]. Foster, A., Renikoff, S. (2005). The impact of vision 2020 on global blindness. Eye. 19: 1133-1135.

[2]. Hans Limburg \& Allen Foster. (1998). Cataract surgical coverage: An indicator to measure the impact of cataract intervention programme. Community eye. Health. 11(25): 3-6.

[3]. Nirmalan, et al. (2002). A population based eye survey of older adults in Thirunelveli districts of south India: Blindness cataract surgery and visual outcome. Br.J. Opthal. 86: 505-512.

[4]. Jha, K.N. (2008). Spectrum of ocular diseases at a military hospital in Ladakh, North India. Journal of clinical and diagnostic Research. 2(3): 843-846.

[5]. World Health Organization. (2000). Preventing Blindness in Children: report of WHO/IAPB scientific meeting. Finger RP.(2007) Cataracts in India: current situation, access, and barriers to services over time. Ophthal Epidemiol . 14:112-118

[6]. Dandona L, Dandona R, Srinivas M, et al. (2001) Blindness in the Indian state of Andhra Pradesh. Invest Ophthalmol Vis Sci.;42: 908-916.

[7]. Venkata G, Murthy S, Gupta SK, et al.(2005). Current estimates of blindness in India. Br J Ophthalmol. 89:257-260.

[8]. Thylefors B, N'egrel A-D, Pararajasegaram R, Dadzie KY.(1995) Global data on blindness. Hull World Health Organ. 73:115-121.

[9]. Dandona L, Dandona R, Srinivas M, et al. (2002). Moderate visual impairment in India: the Andhra Pradesh Eye Disease Study. Br J Ophthalmol; 86: 373-377.

[10]. Brilliant GE, Lepkowski JM, Zurita B, Thulasiraj RD, the Operations Research Group. (1991).Social determinants of cataract surgery utilization in South India. Arch Ophthalmol . 109: 584- 589

[11]. Zhu S., Xu J., Yu Q., Liu Q. (1996). the etiology of vision impairment in target population. Yan Ke Xue Bao. 12 (3). 118- 120.

[12]. Cummings, R.G., Mitchell, P. (1997). Alcohol, smoking and cataract: the blue mountain eye study. Arch Opthalmol. 115: 12961303 .

[13]. Michel p, Cumming RG, Attebo K, panchapakesan J. Prevalence of cataract in Australia. The Blue Mount Eye Study. Opthalmology. 1997: 104: 581-8.

[14]. Pokharel, GP., Shrestha, SK., Negrel, AD.,Ellwein, LB. (1998). Prevalence of blindness and cataract surgery in Nepal. Br. J. Opthalmol. 82(6) : 600-605.

[15]. Mac carty, C.A., Nanjan, M.B., Tylor, H.R.(1999). Attributable risk estimates of cataract to prioritize medical and public health action. Invest.Ophthalmol. Vis. Sci. 41: 3720-3725.Weale, R.A. (1980). Br. J. Ophthal. 604: 311-314.

[16]. Miranda Hitti. (2008). Nutrients may cut cataract risk. Web MD Health News.

[17]. Xu J, Yu Q, Zhu S, Liu Q. (1996). A population-based study of lens opactities. Yan Ke Xue Bao. Sep;12(3):115-7.

[18]. Erie, J.C., Baratz, K.H., et al. (2007). Incidence of cataract surgery from 1980 through $2004: 25$ - year population based Study. J. cataract refract. Surg. 33: $1273-1277$.

[19]. Silvana Artioli Schellini, Shane R Durkin, Erika Hoyama, Flavio Hirai, Ricardo Cordeiro, Robert J Casson, Dinesh Selva, Carlos Roberto Padovani. (2009).Prevalence and Causes of Visual Impairment in a Brazilian Population: The Botucatu Eye Study. BMC Ophthalmology. 9:8

[20]. Bickol N Mukesh (2006). Development of cataract and associated risk factors. Arch ophthalmol. 124: 79-85.

\begin{tabular}{|c|c|c|c|c|c|}
\hline \multirow{2}{*}{$\begin{array}{l}\text { financial } \\
\text { years }\end{array}$} & \multirow{2}{*}{ population } & \multicolumn{4}{|l|}{ cataract } \\
\hline & & number & prevalence $\%$ & $P$ value & $\begin{array}{ll}\begin{array}{l}\text { prevalence/ } \\
\text { population }\end{array} & 10,000 \\
\end{array}$ \\
\hline $2005-2006$ & $21,15,592$ & 5,589 & 0.26 & \multirow{6}{*}{$\begin{array}{l}0.0011^{*} \\
0.0010^{*}\end{array}$} & 26.42 \\
\hline $2006-2007$ & $21,16,878$ & 5,715 & 0.27 & & 27.00 \\
\hline $2007-2008$ & $21,18,164$ & 5,610 & 0.26 & & 26.49 \\
\hline $2008-2009$ & $21,19,450$ & 5,253 & 0.25 & & 24.78 \\
\hline $2009-2010$ & $21,20,736$ & 6,762 & 0.32 & & 31.89 \\
\hline $2010-2011$ & $21,21,943$ & 7,931 & 0.37 & & 37.38 \\
\hline
\end{tabular}

Table.1-Prevalence of cataract among the total population in Alappuzha district.

\begin{tabular}{|c|c|c|c|c|c|c|c|c|c|}
\hline \multirow[t]{2}{*}{ sex } & \multicolumn{6}{|c|}{ financial years } & \multicolumn{3}{|c|}{ cataract } \\
\hline & \begin{tabular}{|l|}
$2005-$ \\
06
\end{tabular} & $\begin{array}{l}2006- \\
07\end{array}$ & $\begin{array}{l}2007- \\
08\end{array}$ & $\begin{array}{l}2008- \\
09\end{array}$ & \begin{tabular}{|l}
$2009-$ \\
10 \\
\end{tabular} & \begin{tabular}{|l}
$2010-$ \\
11 \\
\end{tabular} & total & $\begin{array}{l}\text { percentage } \\
(\%)\end{array}$ & $\begin{array}{l}\begin{array}{l}\text { P Value } \\
\text { (remarks) }\end{array} \\
\end{array}$ \\
\hline male & 589 & 658 & 623 & 708 & 545 & 649 & 3,772 & 39.4 & \\
\hline $\begin{array}{l}\text { fema } \\
\text { le }\end{array}$ & 919 & 994 & 916 & 936 & 1,039 & 999 & 5,803 & 60.6 & \\
\hline total & 1,508 & 1,652 & 1,539 & 1,644 & 1,584 & 1,648 & 9,575 & 100 & $\begin{array}{l}0.0000344 \\
\text { (highly } \\
\text { significant) }\end{array}$ \\
\hline
\end{tabular}

Table.2 - Gender distribution \& prevalence percentage in Alappuzha district 


\begin{tabular}{|c|c|c|c|c|c|c|c|c|c|}
\hline \multirow[b]{2}{*}{$\begin{array}{l}\text { age } \\
\text { grou } \\
\text { p }\end{array}$} & \multicolumn{6}{|c|}{ financial years } & \multicolumn{3}{|c|}{ cataract } \\
\hline & $\begin{array}{l}200 \\
5- \\
06\end{array}$ & $\begin{array}{l}20 \\
06- \\
07\end{array}$ & $\begin{array}{l}200 \\
7- \\
08\end{array}$ & $\begin{array}{l}200 \\
8- \\
09\end{array}$ & $\begin{array}{l}20 \\
09- \\
10\end{array}$ & $\begin{array}{l}20 \\
09- \\
11\end{array}$ & $\begin{array}{l}\text { tota } \\
1\end{array}$ & $\begin{array}{l}(\% \\
)\end{array}$ & $\begin{array}{l}\text { P value } \\
\text { (remarks) }\end{array}$ \\
\hline $0-15$ & 6 & 12 & 14 & 6 & 12 & 10 & 60 & 0.6 & 0.0878 (NS) \\
\hline $\begin{array}{l}16- \\
40\end{array}$ & 20 & 26 & 14 & 28 & 30 & 25 & 143 & 1.5 & 0.0771 (NS) \\
\hline $\begin{array}{l}41- \\
50\end{array}$ & 99 & $\begin{array}{l}10 \\
2\end{array}$ & 64 & 110 & $\begin{array}{l}10 \\
8\end{array}$ & $\begin{array}{l}10 \\
1\end{array}$ & 584 & 6.1 & $0.065(\mathrm{NS})$ \\
\hline $\begin{array}{l}51- \\
60\end{array}$ & 299 & $\begin{array}{l}31 \\
2\end{array}$ & 302 & 307 & $\begin{array}{l}32 \\
6\end{array}$ & $\begin{array}{l}32 \\
1\end{array}$ & $\begin{array}{l}1,8 \\
67\end{array}$ & $\begin{array}{l}19 . \\
5\end{array}$ & $0.00023(\mathrm{HS})$ \\
\hline $\begin{array}{l}61- \\
70 \\
\end{array}$ & 617 & $\begin{array}{l}65 \\
6 \\
\end{array}$ & 625 & 665 & $\begin{array}{l}62 \\
4 \\
\end{array}$ & $\begin{array}{l}66 \\
2 \\
\end{array}$ & $\begin{array}{l}3,8 \\
49 \\
\end{array}$ & $\begin{array}{l}40 . \\
2\end{array}$ & $\begin{array}{l}0.000044 \\
(\mathrm{HS})\end{array}$ \\
\hline $\begin{array}{l}71- \\
80 \\
\end{array}$ & 395 & $\begin{array}{l}45 \\
6 \\
\end{array}$ & 436 & 460 & $\begin{array}{l}39 \\
2 \\
\end{array}$ & $\begin{array}{l}44 \\
5\end{array}$ & $\begin{array}{l}2,5 \\
84\end{array}$ & $\begin{array}{l}27 . \\
0\end{array}$ & $\begin{array}{l}0.000172 \\
(\mathrm{HS})\end{array}$ \\
\hline $\begin{array}{l}\text { 81- } \\
90\end{array}$ & 69 & 83 & 78 & 64 & 88 & 79 & 461 & 4.8 & $0.085(\mathrm{NS})$ \\
\hline $\begin{array}{l}91- \\
100\end{array}$ & 3 & 5 & 6 & 4 & 4 & 5 & 27 & 0.3 & $0.43(\mathrm{NS})$ \\
\hline total & $\begin{array}{l}1,5 \\
08\end{array}$ & $\begin{array}{l}1,6 \\
52\end{array}$ & $\begin{array}{l}1,5 \\
39\end{array}$ & $\begin{array}{l}1,6 \\
44\end{array}$ & $\begin{array}{l}1,5 \\
84\end{array}$ & $\begin{array}{l}1,6 \\
48\end{array}$ & $\begin{array}{l}9,5 \\
75\end{array}$ & $\begin{array}{l}10 \\
0\end{array}$ & \\
\hline
\end{tabular}

NS- not significant HS- highly significant

Table.3-Age distribution \& prevalence of cataract in ALPA district. 